Dragan Bataveljic ${ }^{1}$

University of Kragujevac

Faculty of Law

\section{Dusan Jerotijevic ${ }^{2}$}

Universiti Union ,Nikola” Tesla

Faculty of Business and Industrial Management

\section{Dejan Logarusic ${ }^{3}$}

Sid Municipality
SCIENTIFIC REVIEW ARTICLE doi:10.5937/ekonomika1604141B

Received: November 02, 2016

Accepted: December 12, 2016

\title{
A COMPARATIVE ANALYSIS OF THE MOST POPULAR MODELS OF LOCAL GOVERNMENT
}

\begin{abstract}
The authors point to the fact that the local government in Europe has a long tradition, so that in each of the European countries meet certain specifics regarding the structure, functioning and other characteristics, by which these countries differ from each other. It is quite natural, because such differences are a result of numerous factors that are, more or less, exerted influence on the formation of local self-government (its organization, jurisdiction code, position in society, the relationship between the state and the like). The authors pay special attention and give an analysis of the four major (the best known) model of local self-government - Britain, France, Germany and the United States. England and the United States can be considered the cradle of direct and independent forms of local government, while France was a prime example of the dependent (child) and indirect local government. In modern constitutional systems of much greater application has a two-stage local government, and its chief representative of the Federal Republic of Germany. Finally, there are some systems that do not distinguish between the state and local government, ie. between their bodies, because in such systems the organization of state power is unique and that, from the top all the way to the to the bottom (for example, the former Soviet Union, today's People's Republic of China and others).
\end{abstract}

Key words: local government, England, the French Republic, the Federal Republic of Germany, United States, comparative analysis

JEL Classification: H70, K4

\section{УПОРЕДНА АНАЛИЗА НАЈПОЗНАТИЈИХ МОДЕЛА ЛОКАЛНЕ САМОУПРАВЕ}

\section{Абстракт}

Аутори у раду указују на чињенииу да локална самоуправа у Европи има веома дугу традицију, тако да у свакој од европских земаља срећемо

\footnotetext{
${ }^{1}$ opstanak.kongres@gmail.com

2 dusanjerotijevic@gmail.com

${ }^{3}$ logis.d@hotmail.com
} 
одређене специфичности у погледу структуре, функиионисања и других карактеристика, по којима се ове земље међусобно разликују. То је сасвим природно, јер су такве разлике последица бројних околности, које су, мање или више, изврииле утицај на формирање локалне самоуправе (юену организацију, број надлежности, положај у друштву, однос према држави и слично). Аутори посвећују посебну пажњу и дају анализу четири најзначајнија (најпознатија) модела локалне самоуправе - Енглеска, Франиуска, Немачка и САД. Енглеска и САД се могу сматрати колевком непосредног и независног облика локалне самоуправе, док је Франиуска главни пример зависне (подређене) и посредне локалне самоуправе. У савременим уставним системима много већу примену има двостепена локална самоуправа, а њен главни представник је Савезна Република Немачка. Коначно, постоје и такви системи, који уопште не праве разлику између државе и локалне самоуправе, тј. између њихових органа, јер је у таквим системима организација државне власти јединствена и то, од врха, па све до самог до дна (на пример, бивши СССР, данашьа НР Кина и друге).

Кључне речи: локална самоуправа, Енглеска, Република Француска, Савезна Република Немачка, Сједињене Америчке Државе, упоредна анализа

\section{Introduction}

Local government is a specific and very significant form of organization of power, which, as such, is accepted in almost all countries of the world. However, it should be noted that each of these forms in different parts of the world has its own characteristics, so that they differ among themselves, and these differences are due to many factors, such as, for example, tradition, customs, historical circumstances, the level of economic development, functioning, organizational structure, type and number of service delivery, scope of responsibilities, activities, normative and financial independence, the size of territory, population, and the like. Therefore, in order to have a true picture of local government in the world, try to point out the most important similarities and differences between local self-government accepted in some countries of the world, which, through a historical period shown (and today show) as a very stable and successful. The main indicator of stability is several decades (and centuries of somewhere) the application, the most important indicator of the success of certain forms of local self-government is fast and efficient to satisfy the basic needs of many residents in the local community. Despite the different treatment of local government, as before, so today, we must admit the fact that this form of organization of power in a growing number of countries experiencing their rehabilitation and return to the "big door", because it is beyond doubt that he is one of the basic pillars of democracy. As such, this form of organization and structuring of the authorities, a significant civilizational heritage and important feature of the democratic order. 


\section{England}

Before going into the details of English local government, we will point to the fact that England is one of four countries, in addition to Scotland, Wales and Northern Ireland, which forms an integral part of the United Kingdom of Great Britain and Northern Ireland (English United Kingdom of Great Britain and Northern Ireland). It should be noted that all these countries have a long tradition, but also the special characteristics and specific, concerning local government of each of the said Party of the United Kingdom, which has a government, based in London. At this point, we will not dwell analyzing all the local government, but we part of this chapter taking stock of local government in England, which has great importance for the emergence and development of this form of organization, both in Europe and in the United States. Namely, the local government in England is an indigenous institutions and it is very long developed independently and in relation to the central government, so this form is among the most developed in the world.

England local government, which has a centuries-old tradition, has received its structure and shape, not only parliamentary acts, but also a variety of charters, which have an established corpus jurisdiction of the central (central government) and the local level (local government). These two systems are separate systems, which delegated its jurisdiction is completely autonomous, so that no central authorities can not interfere in the work of local governments. Hence, local authorities have a number of responsibilities and the same work independently, without any interference of central and transferring their operations to the local level so that they do not possess the powers of supervision of local authorities. These are two separate and independent systems. All of this is influenced by numerous authors eighteenth and nineteenth centuries, considered England homeland of local government and local self-government itself, which in the twentieth century had its peak of development, on the basis of constitutional democracy. Hence England is represented an example for many other countries for the organization of local government in them, except that in this island country, local government has experienced at the end of the twentieth century significant changes, in the sense that the state is received by the designated authority to local authorities, as well as the possibility of directing their work. And despite the fact that these reforms, local self-government given some financial support from the government, mentioned changes is a former independent position of local government, to some extent, reduced.

However, what is characteristic of English local government, is the fact that it is three-stage. These are: 1) districts (counties); 2) counties (districts), and 3) parishes (parishes), provided that London, as the capital, has a specific position and organization. Characteristically specify that the local governments have three types of actors, namely: 1) a representative body (local council), which is in charge deciding on major issues related to policy making, financial liabilities, elections and the like; 2) executive bodies (committees or committees), which consists of members of the local council and the citizens that this representative body (not voters), co-opted by its decision, ie. elects and supplemented with the new members; 3 ) the service of citizens (civil service), which is composed of professional staff, trained to perform the tasks of local government and are independent in relation to politics and parties (they are outside of the current policy and are not members of political parties). 
In Britain, between 1960 and 1985, carried out certain reforms, which are of great importance for the functioning of this form of organization, which resulted in the adoption of certain laws. Thus, in 1972, passed the Law on Local Self-Government, which stipulates that the local authority in this island country is carried out in much larger units, which have a much larger population than other European countries. Thus, for example, we have a local government unit with an average population of 123,000 , while in France it is much smaller (only 1,300), 18,000 in Denmark and in Sweden nearly 30,000 inhabitants. (Davitkovski, 1997: 19-26) Here's characteristics indicate that a significant reform of local government in England and carried out in 1985, the Law on Local Self-Government, when they established the so-called. joint government and so-called. universal power - first established for each metropolitan district, while others were basic to the capital London and metropolitan districts. Partial reform was carried out in 1994, when it passed the law on the police and the magistrate courts, which was provided to police authorities no longer be part of the so-called. joint government, but to become independent units.

Local authorities in England have a number of very significant responsibilities, with respect to this island country has a well-developed local self-government, there is very little supervision of the central organs of local self-government. As the largest local governments, according to districts (there are a total of 53), among which we distinguish between two types: metropolitan and ordinary. Districts are divided into districts, ie. districts (there are 369), in which also distinguishes two types: metropolitan and ordinary. Finally, the parish as the basic unit of local government, representing the traditional medieval institutions and in England there are about 10,000.

In the final analysis the local government in England and creating the general picture of its functioning, it is necessary to specify the Local Government Act of 2000, which stipulated that each local unit performs division of local government in a way that will make the introduction of a the local authority, which is directly elected, and it can be: 1) the mayor - is directly elected mayor and cabinet - indirectly cabinet is assembled from at least two or more members of the panel; 2) Cabinet with the leader - here are a leader elected by the Council; 3) the mayor - is directly elected and manage higher - sets it up as a high-ranking official, in whose hands is all power. However, what is important to stress, which is due to reforms carried out in the last decades of the twentieth century, as well as the newest Law from 2000, is that it can be easily seen that effort, as we mentioned previously, the local government in England to become called. "The service of citizens", and that local authorities are, in large degree, the so-called. "Service features". This means that in this country there is a clear desire that these organs operate primarily in line with market demand, which will lead to greater accountability and efficiency of the service, and consequently, to deliver high-quality services. What definitely contributes to networking, development of information technology, fast communication and adapting to local service requirements and user needs.

Also, what is very important to emphasize on the issue in the Law on Local SelfGovernment in 2000, is the fact that it allows more frequent elections of members of local councils, which provides an opportunity for citizens to give their vote of confidence in these panels. Because of these changes, as a result of the democratization of the electoral process and control of local councils, improved local democracy, as well as providing services to residents of local communities. All this, of course, affects the open work of 
local authorities and increase their interest in meeting the needs of its citizens. When it comes to the election of members (councilors) of local councils in England, it should be noted that the said Local Government Act provides for three ways of filling of seats: 1) general elections, which exist in the event the mandate of the council members is four years, so that all Councillors are elected every four years; 2) elections half, which allow you to select (change) half of the council members every two years and 3) a third of elections, which mark the selection for three consecutive years by one-third of the members, within each mandate period of four years. (Dimitrijevic et al., 2011: 151-152)

At the end of this analysis, it should be pointed out that in England we distinguish between mandatory and optional local government affairs. This division is made according to the criteria for statutory conduct certain tasks so that, in the first case, we have jobs that local governments must carry out, while in the second case, the jobs they can perform, but you do not have to (have the right to do so ). Also, it is important to emphasize that the tasks are carried out exclusively in local communities include education, local planning, road construction, transport, housing and construction, sanitary services, social services, waste collection and disposal and the like, while the jobs held by central Authorities includes such activities, which other countries consider local affairs (in such jobs include, for example, health care, social security, finance, agriculture, etc.). However, despite the fact that there is such a division of labor, in England there is a policy less government interference in the affairs of local government, ie. enabling local authorities that they, as far as possible, provide local services to their populations. (Byrne, 2000: 82-83)

\section{The French Republic}

Given that the state system of the Republic of France for a long time it was centralized and based on a strict hierarchy, at the beginning of this analysis, it should be noted that the local government in the mentioned European country almost did not exist until 1982, when the program started decentralization and enabling autonomy of local government. The degree of self-management of local authorities was extremely small, because the local government is exercised quite narrow scope of work in its own jurisdiction, which were of minor importance in relation to the tasks that fell into the Trust (transfer) scope of work. However, the advent of the presidency of the French Republic François Mitterrand in 1981, things in this respect are starting to change for the better, so that, from next year, in 1982 there was a significant independence of local governments and the process lasted until 2003 . year. This has affected the position of the French local government keep its trend to the present day, so that this form of organization of power in France is no longer an example of complete subordination to the central government. This situation shows that the local government, as well as many other institutions, is not static and unchangeable, but rather a very dynamic phenomenon, which is subject to constant changes. This was particularly contributed to the adoption of the Law on decentralization of 1982, when as part of the reforms implemented, established regions, which were given the status of self-governing units, which the local government has become a three-stage.

For the French Republic, which is one of the pillars of European democracy, it should be noted that, according to the surface, and according to population, one of the 
largest countries in Europe. Hence, in this country, a member of the European Union and one of its founders, has an important place both in terms of organization of local self-government, which has traditionally been a two-stage, given that in its grounds contained two local units - the municipality (commune) and department ( département). The introduction region (s) the eighties, as territorial units of general jurisdiction, the French local government has become a three-stage. It should be noted that in France there is the so-called. monotype municipalities, which means that all municipalities (both in cities and those in villages) have equal status. These municipalities (communes) are very numerous and there are more than 36,000 , given that they fall into the category of very small units, but it should be noted that (although, admittedly, there is very little) in the municipality includes the towns numbering more than 50,000 inhabitants. Of course, it is important to note that three of the city, although they are in the commune, have a special status, which is quite understandable, given their importance, size, number of inhabitants and the like. These cities include Paris, as the capital, and next to him Lyons and Marseille, which unlike the other cities, can form within its area of urban districts (arrondissements). These districts within the three listed city, represent specific units of local government, and they were introduced by the Law of 1982, which was adopted by the French Parliament.

In this paper, we will not dwell on the historical development of local government in France, but it is certainly necessary to point out that the municipalities of the community, whose origin and development encountered in the Middle Ages, while the emergence of second level of local government responsible Napoleon Bonaparte, who formed departments, as some kind of connection, ie. "Links" between higher and lower levels of government (between the center and municipalities). Hence the departments represented the central government level, and their introduction to Napoleon's system of organization of government, was, in fact, the deconcentration of power, because it is a strict hierarchy between the lower and higher authorities, represented the basic principle of establishing their relationship. This led to the fact that one of the most developed model of local government (the French self-governing communes) was repealed and replaced by a rigid centralism, so that this system was awarded a small degree of self-management, and the very term "local government (administration locale) hinted at the true state things ". (Jovicic, 1984: 171) However, it should be noted that you did not stop and that this devolution of something later replaced by a special form of self-government, which is called administrative decentralization, while during the existence of the Third Republic any attempt to find solutions that would constitute some sort of compromise between the local government and centralism. Further progress in achieving independence and the abandonment of the centralist state organization made in 1946, when the Constitution was adopted, which is the local government (the first time) received the constitutional and legal character. This is done in a way that was done declaring self-management of local collectives in which fall municipality and department, the most important event in this area was the adoption of the law made in 1982.

Wrapping up this part of our work is dedicated to the analysis of the French local government, we must be emphasized that local governments in France and England, who used to be diametrically opposed, gradually approaching, because the French model comes to light but secure decentralization, while in English the model comes to mild centralization. This means that increasingly abandoning strict hierarchical relationships between central 
and local authorities and embrace a different model of organizing the relationship between the central government and local governments. In fact, in recent decades applied a number of ways to overcome the existing situation in the field of French local governments, which include: 1) numerous proposals for enlarging municipalities voluntary merging small municipalities; 2) Association of Municipalities union of municipalities and 3) introduction of the region. However, it should be noted that this process is going quite slowly because there is a fear of the central government to make some significant steps to reform the municipalities, ie. their merger (fusion) in the broader territorial units. This fear exists with reasons such as enlarging the (incorporating) Municipality requires greater self-government and the wider decentralization, and this could lead to a weakening of the power of the central government. (Popovic, 1984: 18-23)

The second stage of organization represent the department (there are 100), and the French departments Handicraft has its roots in the French Revolution of 1789, led by the prefect of (PREF). The prefect is the representative of the central government and the executive organ of the general higher, but for this position, the person who enjoys great prestige and authority and has significant political prestige gained professional experience in their work. As already noted, the connection (link) between the department and the municipality represent districts, with what municipalities are subordinate departments, and through them the central authorities (ie, indirectly). On the other hand, the departments are directly responsible for their work to the central authorities and they are subordinate. Also, it is important at this point to mention that the representatives, and municipalities and departments (primarily, their presidents), important factors work of local authorities.

Analyzing the Local Governments in France, we pointed to the fact that the second stage of self-government is composed of 100 departments, but four of which are located far away from France, given that she was one of the greatest colonial countries. These are the overseas departments, which are also the regions, so that they have a dual status, while the remaining 96 departments located in France itself. All of these include the department, approximately the same number of municipalities (about 380), regardless of what they each are very different in terms of population, so that the smallest has about 75,000 inhabitants, most about 2,500,000 inhabitants (the average is around 450,000 inhabitants).

The third level of local government in France, or the third level of the system of self-government make the regions, which were created at mid-century, for smoother economic development departments and municipalities. However, it should be stressed that the regions are given self-governing status in 1982, when certain reforms have decentralized, so one can say that the regions in its present form, emerged only in the early eighties. Specifically, as part of three-tier local governments (in addition to municipalities and departments), regions have become the only in 2003, when the constitutional changes were made and when they were provided for by the Constitution. Here we should point out the fact that in the last months of 2008 announced new local government reform (the reform announced by then President of France, Nicolas Sarkozy), but in this area of further reforming of the French local government and the rest, because nothing has been done to today, because of the very strong opposition of local political power.

What is characteristic for the region, is the fact that the population in them is very different, and that is in the range of 1,000,000 to 5,000,000 (actually, less than one 
million to over 5,000,000), while their average area of around 25,000 square kilometers. Also, as a significant feature of local government in France is the fact that certain areas are special, that is. special status and this is not in accordance with the principle of regional organization of the state. The special status of certain areas is the result of certain events in the history of this major European states. This includes, first of all, decolonization, then the existence of cultural differences, as well as the characteristics of a large city (metropolis). However, it should be pointed out the fact that the French local self-government performs specific cooperation of local communities, which may be political cooperation (may take the form of political cooperation), and that there are other forms of cooperation. With the political cooperation of the municipality (which belong to the same political orientation) assist each other and form trade unions, districts, communities, municipalities and the like, and like other forms of cooperation may indicate conventions, groups of public interest, joint ventures, associations and the like.

It should be noted that a special role in the realization of political cooperation between the municipalities of trade unions, which is a term that refers to a group of municipalities, which shall be established precisely in order to resolve common problems of infrastructure (electric networks, water supply, sanitation, etc.). For the community of municipalities is significant that this is a relatively new form of intermunicipal cooperation, and in this form has allowed a greater degree of integration of the municipalities which form the community. The main objective of this association of municipalities, is the realization of inter-municipal solidarity (as a subset of the community of municipalities, can form communities and cities so far has established five such communities). Also, since 1959 there are districts, which include a lower degree of integration and municipalities may be established at the proposal of several municipalities, with what could be established for rural areas (hence abandoned the original proposal that called "alliance of cities ").

\section{The Federal Republic of Germany}

Strong loyalty to tradition and traditional values is one of the fundamental characteristics of the German administrative system, which is characterized by the following features: 1) the existence of the federation, ie. Federal Planning; 2) territoriality administrative system (not its functionality); 3) the specific value the rule of law; and 4) an extremely high value attributed to local self-government. (Laux, 1995: 229) Also, what is very important to emphasize at this point, is the fact that the organization of the Federal Republic of Germany has experienced a number of reforms (some authors from the early nineteenth century to the twentieth century, there were 11 major reforms, for which it was more than 40 important reform undertakings), which, of course, had its impact on the position, competencies and attributes of local government. Specifically, these changes have affected that substantially reduced the number of municipalities, and this decrease was the highest percentages, result of a great acceptance of the so-called. "New management model" and a significant increase in costs for social welfare state.

Every reform is undertaken in order to achieve certain goals and correct shortcomings observed in the functioning of a particular system, and such change in Germany organized by the authorities had basic orientation to increase cost-effectiveness, 
the implementation of market economy and laws of the market in all segments of the society, where this is possible, as well as the precise separation of politics from administration, ie. delineation of the functions of decision making and execution functions. It is obvious that the creators of these reforms have had in mind the application of methods of economic management and planning towards the objectives set.

Germany local government is an institution that guarantees the highest general legal act, ie. Basic Law of the Federal Republic of Germany (Article 28, paragraph 1 and 2). On the Name, the provisions of this Article, the activities of the local community, within the law governing cities and municipalities. For this developed European country, it is characteristic that in it there is the territorial decentralization and that can be classified as major countries, both in terms of population, and by the area it covers. The above mentioned Constitution (Basic Law) of 1949, Germany is organized as a federal state with a governmental structure on two levels, namely: federal and provincial (terrestrial) level. As part (constituent) parts of these countries, which make up the Federal Republic of Germany, municipalities and counties have a vital role in the functioning of local government, given that competence rather clearly and precisely divided between the federal and earthly levels. This is especially true for local governments, because at the highest level creating legislation and policies, while at the lower level to implement them in practice. Local governments in Germany enjoys a large degree of autonomy, so that in this country has not implemented decentralization like other European countries.

What is characteristic for the organization of government in Germany, is the fact that even after reintegration of the 5 provinces (states) of the former GDR, remained in force Constitution of the Federal Republic of Germany from 1949 to the current 16 federal units (the Länder) are almost complete freedom (autonomy) in the organization and regulation of local government. This allows the provinces to independently regulate the functioning of local self-government and set basic (most importantly) the institutional parameters for its functioning. However, it is important to point out one important feature of the German local government, which consists in the fact that even though there are big differences in the surface of the territory covered and the population in some federal units, there are no essential differences in the territorial organization of the German local government. On the contrary, there are great similarities in the organization of the local population of these countries, so that many authors find that for local governments of all 16 countries that make up the German federation, the characteristic uniformity and in quite a high level.

The Federal Republic of Germany is today, its local self-government organized as a two-step. The first level of local government consists of municipalities (Gemeinden), as the basic unit, while the second stage consists of terrestrial districts (Landkreise) and district towns (Kreisfreie Cities). After the fall of the Berlin Wall and the unification of the two Germanys, the area of this major European states, there are 13,400 municipalities, which are located in the system 343 Land district, at Com should be noted that, on average, a district in its composition has about 30 municipalities and has between 150,000 and 200,000 inhabitants. (Wallmann et al., 2006: 11-39) A significant feature of the German local government, is the existence of 117 major cities, carrying out tasks under the responsibility of municipalities and districts, so that they are much closer to the provinces (countries) and are under the direct supervision of its authorities. Due to limited space in the paper, especially due to the major themes to which he devoted, in 
this paper we will not longer dwell analyzing certain deviations from the German twotier structure of local government, referring to the three city-states (Berlin, Hamburg and Bremen) in which the local government is organized as a single stage. Also, a very important feature of these governments is the fact that the German federal units, which are composed of more than 20 districts and district towns, formed their own regional administrative units (Regierungsbezirk). Through these regional units earthly authority supervising the implementation of local government, although there is a tendency that this kind of supervision revoked and that these units are converted into units that would serve local self-government.

In addition, Article 28 of the Basic Law of the Federal Republic of Germany, it is anticipated that the scope of self-management activities, performed by municipalities and counties, to be arranged by the method of general clause, according to the constitutional tradition of the nineteenth century, although local governments have the right to independently determine the internal organization. Excluding the possibility of influencing the federal and provincial authorities to the activities of local government, the result is exactly above the rights of local units, which represents a fundamental feature of local government. Also, a significant feature of the German local government, in which it stands out from the other (together with the Austrian local government), are called. duality of functions, whereby municipalities and districts, in addition to their own affairs, conduct and duties transferred from the state level. In fact, about the importance of local government and the role it has today in the Federal Republic of Germany, there is a data that around $3 / 4$ of federal and terrestrial legislation achieved at the local level. Such a high percentage achieving tasks at higher levels to the lowest level, resulting in the fact that the German local government the most developed and that plays a more important role in relation to local governments of other European countries. Also, for the Federal Republic of Germany can be said that it is located at the top of European countries that conducted direct local democracy, so there was no need for public sector reform, which was conducted eighties. However, the nineties of the last century, under the influence of New Public Management, accepted the new doctrine of public management, which has spurred the creation of the German version of this management, ie. Tilburg new management model. (Banner, 2006: 126-127)

Based on the above it can be concluded that the state structure of the Federal Republic of Germany has three levels, and the third (most important) level is, indeed, local government authorities, which are, at the same time, the foundation stone on which is based the state itself. This is because, as we have mentioned previously, most of the laws implemented by local authorities, and to facilitate the realization of the most direct contact with citizens. Considering that the achievement of these direct contacts "fraught" with the emergence of numerous conflicts, the Basic Law of the Federal Republic of Germany in 1949, its provisions guaranteeing institution of local government. This institution is important, first of all, because while editing the affairs of local communities need to enable municipalities to, as far as possible, meet the local needs and requirements of citizens.

It is obvious that the local government in the Federal Republic of Germany has many positive features, but also certain disadvantages and limitations. However, the principle of local self-government in this country is, as before, and today, remained in the application and is extremely important for building self-management system, whose 
implementation regularly look after administrative and constitutional courts. So, first of all, municipalities is guaranteed to them, in any event, can not take away jobs that belong to the "local jobs", so in the event of interference with the exercise of certain tasks, the legislator has an obligation to justify it and to present adequate reasons, which can prove that such action is necessary. This has certainly contributed to the well-known territorial reform of municipalities, which was carried out in West Germany in the middle of the second half of the twentieth century. The aim of this reform was to edit the municipalities and districts, but so that the minimum administrative authorities provide both small municipalities, which resulted in a substantial reduction in independent municipality, by almost $2 / 3$, ie. from 24,000 to 8,500 . Also, there was a reduction in the number of free cities 135 to 91 , then the number of districts from 425 to 236 and the number of municipalities that belong to a district with 24,300 in 8400 . Local government reform is carried out, after the unification of the two Germanys (1990) and in the provinces of the former German Democratic Republic - GDR (German, Deutsche Demokratische Republik DDR), considering that it was necessary harmonization, that is. the convergence of these two, very different, system. Namely, in East Germany (GDR) is, when unification was more than 7,500 cities and municipalities, while in western Germany the number was much smaller. After the reforms carried out after unification in the new Länder in the former East Germany (there were 5), the number of these municipalities was reduced, but not to such an extent as is the case with the districts. The number of municipalities is now about $\$ 6,000$ in the provinces, while the number of districts was reduced from 191 to 92 and the number of free cities in 24. (Damjanovic, 2002: 20-22)

\section{United States of America}

Keeping in mind the theme of this work, which we posvâtiti its biggest part, in a new place we want only to point out the most important local government system, which had the greatest impact on the formation, development and dissemination of the importance of local governments in other countries. There, above all, think in English and French system (as two antipodes), as well as the German and the American system of local governments - Germany, due to the reforms made, which could serve as a model for reforming local governments in other countries and the US, due to its characteristics and distinctive specificity in relation to other countries. Therefore, we will further in the attention paid to the analysis of local government in the United States, which the local government is the most complex in the world, considering that in this country there are COD and simultaneously operate different types of local government.

In fact, as we saw in the previous section, in English, French and German local governments are unique types throughout the territory of the State in which they are applied, while the situation in the US is completely different, given that in this extremely large, country very organization of local self-government entrusted to the Member States (federal units) and not the federal (federal) state. The result of such an organization and the adopted constitutional principles, is the existence of large differences in local government and, as between Member States themselves, and within the same federal units. The existence of such a significant difference has been brought about not only indicated the possibility of regulations of the Member States, but also the great influence 
of English local government, whose institutions, customs and traditions brought from England's first settlers. Finally, the reasons given diversity we must also mention the very great diversity of individual cities, a complex social life, a sudden and very rapid urbanization and the like. However, despite this diversity and the existence of different types of local government, we can say that in the United States are two main types, namely: 1) the urban form of government (characteristic of cities); 2) rural form of government (typical for rural areas).

What is important to note for local governments in the US, is the fact that the similarity, rather, there is a coincidence in degree. In fact, with the exception of only one country, which is the smallest by area (Roy Island), there's a two-stage local government and so that municipalities (municipality), basic units, while the counties (county) unit of the second degree. Districts are traditional agricultural, territorial and administrative units, so that each member state has from 3 to 254 districts. It is important to point out the fact that, precisely, cities (in most federal units) the most important units of local government and to them there are three models of local self-government. Separate great influence on the development of local government in the United States had England (which can be said for the development of local government in the world), so it's accepted the basic principle of self-organization of local government units, which further indicates that the local government in the United States does not constitute a category of the federal Constitution and federal law. These three main models (systems) local governments are: "1) model mer-council - the first and oldest model in which local voters directly elected mer and advice, and in this way to elect judges and administrative officials; 2) a commission model - sparsely body (Commission), which is directly elected by local voters, simultaneously legislative and executive authorities, so that every member of this commission is managed by an administrative department, 3) management model - experts prefer this third as the most appropriate model, which contains elements of a presidential system authorities “. (Bataveljic, 2013: 193) For this latest model is characterized by through open competition Assembly appoints managers for an indefinite period, which must meet numerous: first of all, it must be qualified and knowledgeable to perform these tasks, then that is not a member of a particular political party (non-partisan) and that As such, completely free and independent in the choice of the closest associates, as well as his engagement provided an appropriate contract, that guarantees an adequate payment for his work.

Analyzing the above models (systems), we will point to the fact that the oldest of them first, which draws its origins back to the English system of local self-government. In fact, this is a model that in the United States being applied and that in more than half of US cities, and it is a characteristic that is based on the existence of the president, ie. measures and advice. However, there is a real difference between the two versions where it is applied and the system operates as follows: 1) variant with a strong measure and 2) variant with a weak measure. Regardless of which option (variant) word, President, ie. mer is the most important organ, since it has very strong democratic legitimacy, because it directly elected by the citizens. Hence he (like the presidential system in the USA) the holder of numerous functions in the city, so that manages the city administration, represents the city, and his officers, the process as the executive organ of the Senate and head of administration. Hence, the president has a very important role, because preparing the most important decisions for adoption by the Senate, has a decisive role (not just 
representative) in solving a number of issues, so, therefore, safe to say that the President, that is. Custom has in the same status, responsibilities and functions, which has the President of the United States in the federation or the Governor in individual federal states. (Djordjevic, 1957: 35-38)

Much less applicable model is called. commission, whose application is linked to the beginning of the twentieth century, with the primary objective of its introduction consisted in the fact that the Commission monitor the efficiency of local authorities, as well as reducing the impact of party organizations in their work. There is no doubt that the Commission is one collegial body, whose members are directly elected by the citizens and which, therefore, can not recall them. As one of the most positive features of this system, we can mention its ease of organized bodies. In addition, he is very rational in the exercise of their activities, whose concentration is also a positive feature of a commission model. However, as it usually happens in all other spheres of social life, this system has numerous weaknesses, which consist primarily the inability to eliminate the influence of party organizations in local government, as well as in its lack of efficiency.

Consequently, the application of a third system that appeared later and which is used in a little over $20 \%$ of US cities. For this system (model) is characterized in that in it there are the two most important organs, namely: 1) Manager (city manager) and 2) higher (to be advised). The very name of the system speaks volumes about the manager (administrator) expert and the head of the administration in the city, which at that position comes not along political lines, but he Council elected as officials with the higher degree of efficiency and skills in order to implement the most important decisions and policy making. The characteristic of its position is in the fact that he was elected for an indefinite period, but advice has the right to revoke it if it does not carry out his duties, as provided. (Djurdjev, 2003: 46-48)

Finally, when talking about local government in the United States, we can not, not to mention self-government in small towns of New England, which is a specific model of local self-government in the United States, where the local government is realized in the so-called. town choirs. Namely, at such gatherings is, once in a year, brings together the entire population of the town and in that occasion, makes decisions on the budget, taxes, choice of certain borough officials, as well as on other important issues. Also, in the New England area, the districts are the judicial institutions of the organization, which is not the case with Western countries, where districts as territorial self-governing units have significantly more numerous functions (not only in the judiciary but also in health care, social protection, the construction of public roads and the like ).

\section{References}

Avramovic, S. \& Stanimirovic, V. (2007). Comparative Legal Tradition. Belgrade.

Banner, G. (2006). Local Government - A Strategic Resource in German Public Management Reform. In: Wollmann, H., Hoffmann-Martinot, V., State and Local Government Reforms in France and Germany. (126-127). Wiesbaden: VS Verlag für Sozialwissenschaften.

Bataveljic, D. (2013). Constitutional Law. Kragujevac: Faculty of Law. 
Byrne, A. (2000). Local government in Britain (7th edition). Harmondsworth.

Crucq, P. \& Hemming, H. (2007). Decentralization and Economic Growth per capita in Europe. University of Groningen.

Damjanovic, M. (2002). Comparative experiences of local governments. Belgrade: Magna Agenda.

Davitkovski, B. (1997). Local government (concept and elements). Local government, Nis, number 1, 19-26.

Dimitrijevic, P. \& Vucetic, D. (2011). The system of local self-government - the norm and process. Nis: Faculty of Law.

Dimitrijevic, P. (2004). Models of local government, the Constitutional issue in Serbia. Nis.

Djordjevic, J. (1957). Basic types of local government. Belgrade.

Djurdjev, B. A. (2003). Local Government Publishing Centre. Novi Sad: Faculty of Law.

Jovicic, M. (1984). Big constitutional systems - elements for a comparative constitutional law. Belgrade: Modern administration.

Laux, E. (1995). About kommunale Organisationspolitik, Archiv für Wissenschaften Jhrg. 34, II. Halbjahresband.

Popovic, S. (1984). Legal status of municipalities and local government in comparative and Yugoslav law. Belgrade: Scientific Book.

Ridley, N. (1988). The Local Right: Enabling going Providing. London.

Rondinelli, DA. (1987). Development Administration and US foreign aid policy. London: Boulder.

Turpin, D. (1998). Droit de la Decentralization. Principes, Institutions, Competences. Paris.

Wollmann, H. \& Geert, B. (2006). State Organisation in France and Germany between territoriality and Functionality. In: Wollmann, H., Hoffmann-Martinot V., State and Local Government Reforms in France and Germany. (p. 11-39). Wiesbaden: VS Verlag für Sozialwissenschaften. 